\title{
Bioerosive structures in orbitolinid foraminifera: examples from the Lower Cretaceous of Central Iran
}

\author{
Felix SCHLAGINTWEIT ${ }^{1}$, Ioan I. BUCUR ${ }^{2}$, Koorosh RASHIDI ${ }^{3}$, \\ \& Behnam SABERZADEH ${ }^{4}$
}

${ }^{1}$ Lerchenauerstr. 167, 80935 München, Germany

${ }^{2}$ Department of Geology, and Center for Integrated Geological Studies, Babeş-Bolyai University, Kogălniceanu 1, 400084 Cluj-Napoca, Romania

${ }^{3}$ Department of Geology, Payame Noor University, Po Box 19395-3697 Tehran- Iran

${ }^{4}$ Ferdowsi University of Mashhad, International Campus, Mashhad-Iran

Received May 2013; accepted September 2013

Available online 3 October 2013

DOI: http://dx.doi.org/10.5038/1937-8602.58.2.1

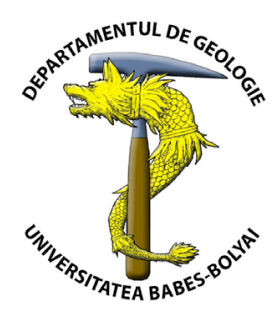

\begin{abstract}
Lower Cretaceous orbitolinid assemblages from Central Iran yield various bioerosional structures. The omnipresent traces of different boring taxa and groups (e.g., sponges, calcimicrobes, incertae sedis) represent a characteristic feature of the investigated thin-section material. The assemblage can be attributed to the Entobia ichnofacies dominated by borings assigned to the activity of sponges. The boring galleries are often concentrated in a plane parallel to the test surface, along the boundary of the marginal and the central zone of the orbitolinid tests. The borings are observed in foraminiferan-dasycladalean wackestones to poorly washed-out packstones, which can be referred to a subtidal palaeoenvironment.
\end{abstract}

Key words: bioerosion, ichnology, orbitolinid foraminifera, bacinellid fabrics, Entobia ichnofacies, Iran, Lower Cretaceous

\section{INTRODUCTION}

Bioerosion, the decomposition of hard substrates of biogenic or abiogenic origin by biological processes such as grazing, etching or boring, is a well known phenomenon in both ancient and modern shallow marine carbonates (e.g., Neumann, 1966; Golubic et al., 1975; Taylor and Wilson, 2003). Numerous organisms are able to actively excavate (or bore) substrates on a macroscale, such as certain bivalves, gastropods, echinoids, sponges, polychaetes, arthropods, bryozoans or benthonic foraminiferans (e.g., Bromley, 2004). Certain groups of cyanobacteria, green and red algae as well as fungi bore on a microscale and are therefore termed microborers. The terminology to separate microborings from macroborings is not uniformly used in the literature. Some consider borings with a diameter of less than a millimetre as microborings (e.g., Flügel, 2004: p. 387; Wilson, 2007), while others take a maximum width of $0.1 \mathrm{~mm}$ as the boundary between micro- and macroborings (e.g., Golubic et al., 1975; Glaub, 1994). Borings are treated ichnotaxonomically even in cases where the producers are known (e.g., Mägdefrau, 1932; Taylor and Wilson, 2003; Bertling et al., 2006, with further references therein). Generally, endoliths within host skeletons sometimes are divided into active borers (euendoliths) or passive settlers (paraendoliths and cryptoendoliths) that thrive in fissures or nestle in pre-existing borings, respectively (e.g., Golubic et al., 1981; Scoffin and Bradshaw, 2000). This distinction may be sometimes difficult in fossil material especially in cases where recent observations are not available.

In Mesozoic to Cenozoic shallow water carbonates, the tests of larger benthonic foraminifera often represent typical substrates for both macro- and microborers (Banner, 1971; Matteucci, 1978; Golubic et al., 1984; Nielsen, 2002; Nielsen and Görmüş, 2004; SenGupta and Nielsen, 2009; Nebelsick et al., 2011; Ćosović et al., 2012). For orbitolinids, especially the presence of small cyrptoendolithic foraminifera inside borings was recorded repeatedly (e.g., Cherchi et al., 1990). The present paper adresses several examples of bioerosional patterns observed in the tests of orbitolinids from the Lower Cretaceous (Barremian-Aptian) of Central Iran.

\section{GEOLOGICAL SETTING}

The mountainous region around Anarak (Nain County, Isfahan Province) belongs to the Yazd Block of Central Iran (Berberian and King, 1981; Aghanabati, 2004, for overviews). Lower Cretaceous shallow-water limestones occur transgressively upon conglomerates and sandstones which in turn are underlain by the Late Paleozoic to Triassic Anarak metamorphic complex (e.g., Torabi, 2011; Buchs et al., 2013). For a geological sketch map of the Anarak region see Torabi (2011, fig. 2).

The Lower Cretaceous shallow-water carbonates of the Yazd Block, which are generally assigned to the Barremian-Aptian interval (e.g., Chahida and Djafarian, 1977), were investigated with respect to microfacies, sedimentology and micropalaeontology by Bucur et al. (2012) and Wilmsen et al. (2013). Three sections are currently under study in the area of Anarak-Naien-Ardakan (Fig. 1): the Anarak section near Anarak and the Herisht sections (T and $\mathrm{H})$ close to Ardakan. First results indicate that the stratigraphy of these carbonates, in Iranian geology often designated as "Orbitolina limestones" (e.g., Stöcklin, 1971), may be highly different (e.g., 
Schlagintweit et al., 2013). In fact, orbitolinid foraminifera represent frequent constituents in these carbonates, mostly wacketo packstones, where bioerosional processes may affect their tests. In the orbitolinid-dominating samples, other bioclasts acting as hard substrates for the boring organisms are represented mostly by remains of dasycladalean algae only. The purpose of the present paper is to illustrate and briefly describe and comment the observed boring traces affecting the orbitolinids. Most of the examples shown are from the Early Barremian of the Anarak section (Fig. 1) where the dating is based on the occurrence of Eopalorbitolina charollaisi SCHROEDER and other taxa (Schlagintweit et al., 2013, for details). Only some examples are from the Early Aptian (Praeorbitolina cormyi zone of Schroeder et al., 2010) of the Herisht section.

\section{DESCRIPTION OF ENDOLITHS, ICHNOTAXA AND BORING PATTERNS}

In the thin-sections studied different types of boring galleries can be observed. Most of them are empty and filled with cement. In

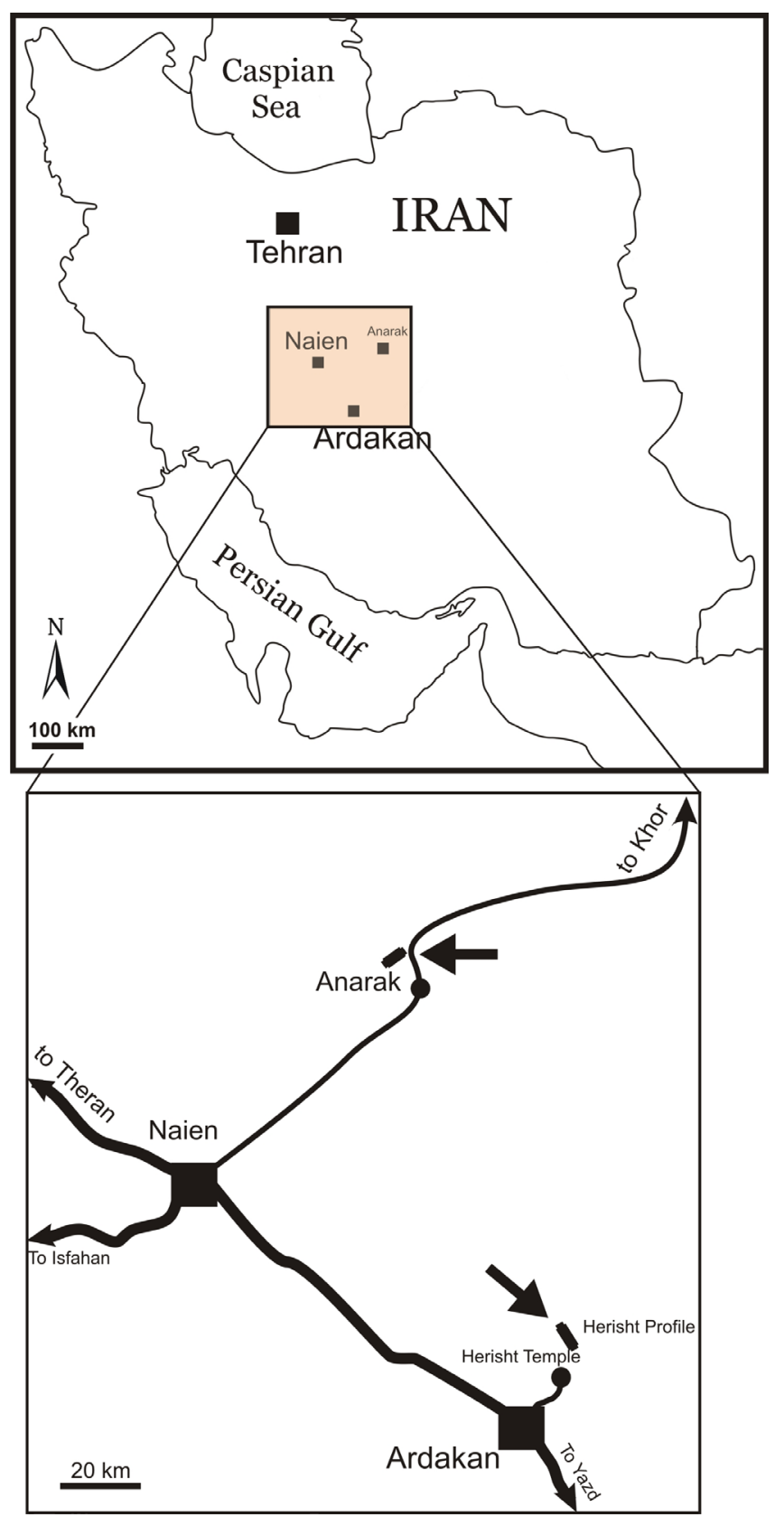

Fig. 1. Locality map of the study area in Central Iran, indicating the position of the Anarak and Herisht sections (arrows). some cases, (micro)organisms can be observed inside the borings. These can be either related to the producer itself (= euendolith) or to a secondary nestler (= cryptoendolith) that entered the borings, for instance as a protective site (Golubic et al., 1981, for terminology). Abundances in the thin-sections were not quantified. The order of the description does not imply abundances or other attributes.

\section{Bacinellid crusts}

Crustose masses of pseudocellular bacinellid textures (sensu Maurin et al., 1985 and Schlagintweit and Bover-Arnal, 2011) are observed enveloping the orbitolinid tests, occasionally also forming bridges between adjacent specimens and thus binding them together (Fig. 2a). The crusts may penetrate deeply into the orbitolinid tests, thereby replacing the original chamber structures. Due to their diffuse outline, these structures most likely represent an active penetration by dissolution/etching processes.

For these textures, a calcimicrobial origin is generally assumed based on rare findings of various types of filamentous structures within the pseudo-cells (Schäfer and SenowbariDaryan 1983; Maurin et al., 1985; Vachard et al., 2001; Granier, 2003; Uţă and Bucur, 2003; Schlagintweit and Bover-Arnal, 2012). In most cases, however, arguments for such an interpretation were not further substantiated, e.g., by thin-section photographs. To illustrate this, two further examples from Lower Cretaceous (Aptian) bacinellid crusts of Spain and Oman are shown in Fig. 3. The relevance of these rare finds is of importance here as an etching potential of these structures was already envisaged by some authors (Neuweiler and Reitner, 1992; Kolodziej, 1997; Granier, 2003). The modern microflora actively penetrating hard substrates has been studied since many decades (e.g., Ercegovic, 1927; Tribollet, 2008; and many others). The taxonomy of fossil counterparts, however, is still poorly known.

\section{Ichnogenus Entobia Bronn}

In the thin-sections studied, Entobia represents the most widespread ichnotaxon within the orbitolinid tests. Due to the random sectioning, different types (that might exist) were not distinguished, as the three-dimensional form remains unknown. Rather, these are collectively attributed to Entobia isp. This Entobia ichnofacies is usually reported from rocky shores and cliff-bound carbonate deposits (e.g., de Gibert et al., 1998; Titschack et al., 2005), the Lower Cretaceous occurrences instead are from subtidal shelf environments of only moderate hydrodynamic energy.

Some perforations are cutting the tests without preferred orientation, while others are arranged in a plane parallel to the test surface, often at the boundary of the marginal zone to the central zone. Single chambers with radiating unbranched canals (Fig. 4d) are present as well as forms exhibiting several smaller chambers with interconnected canals (for terminology see Bromley and D'Alessandro, 1984). Similar structures affecting orbitolinid tests were illustrated by Schroeder (1997, pl. 1, fig. 5) from the Early Barremian of Switzerland as "traces of dissolution at the boundary marginal to central zone" (translated).

\section{Boring of an unknown producer}

This boring pattern is characterized by straight to slightly undulating canals that exhibit a continuous increase in diameter starting from the entrance point at the foraminiferan test (Fig. 5a). Later, the diameter remains constant and branching may occur as well (Fig. 5b). Due to the absence of chambers in the sections 

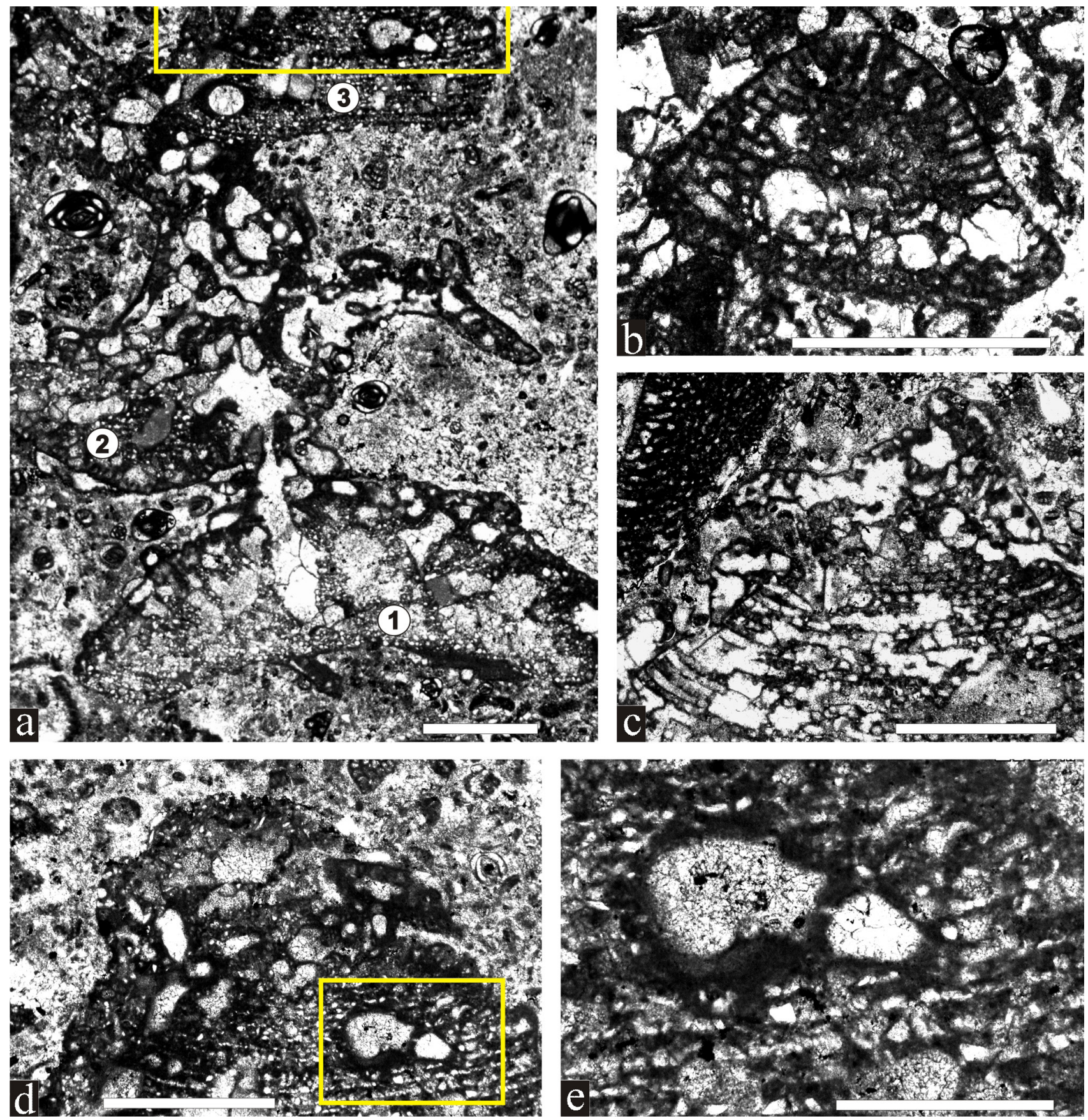

Fig. 2. Bioerosion of orbitolinids by bacinellid crusts; a) Three tests of orbitolinids (1-3) encrusted and thus connected by the crusts. Note the penetration and etching from all sides. The yellow rectangle marks part of the detail shown in $\boldsymbol{d}$. Anarak section, thin-section AQn 24; $\boldsymbol{b}$-c) Test filled partly with irregular bacinellid-type pseudocells replacing the chamber structures of the orbitolinid. Herisht section, thin-section $H$ 43 and Anarak section, thin-section AQ 23; d-e) Details from a, showing the external encrustation and an unknown bioeroding taxon. Note the micritic filling. Anarak section, thin-section AQn 24. Scale bars $=1 \mathrm{~mm}$, except e $=0.5 \mathrm{~mm}$.
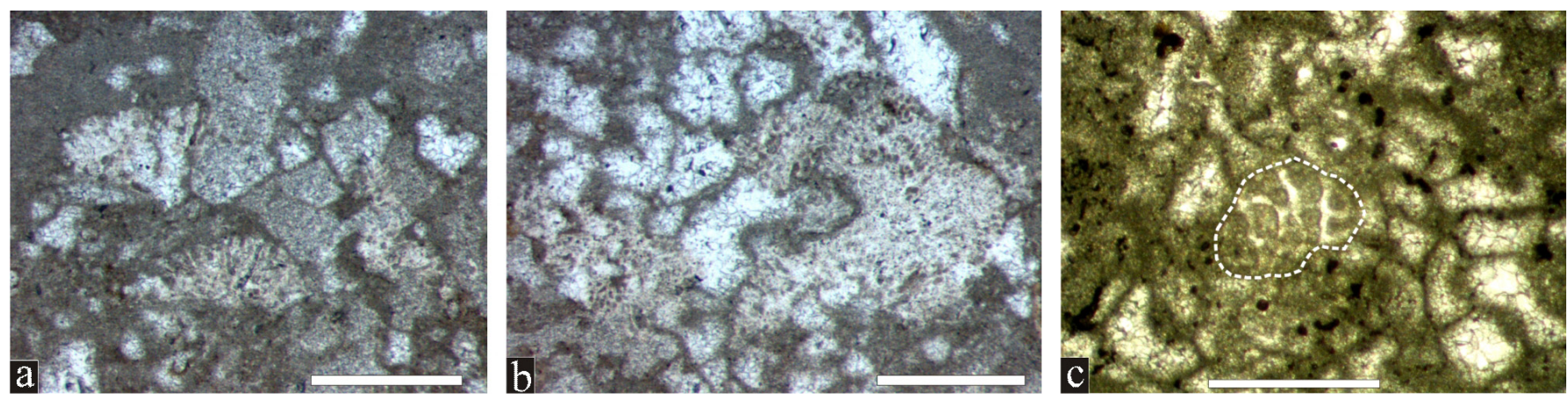

Fig. 3. Filaments of assumed cyanobacterial origin within pseudocells of bacinellid fabrics (see also GRANIER, 2003: Fig. 6); a-b) Bushy filament type (diameter 4 - $10 \mu \mathrm{m}$ ) (?Nostocalean-type), Late Aptian of Spain (leg. S. Huck). (a vertical section, b horizontal oblique section); c) Vertical oblique section of filament-like arrangement of cells (?Chroococcalean-type), Early Aptian of Oman (leg. A. Immenhauser). Scale bars =0.3 mm. 

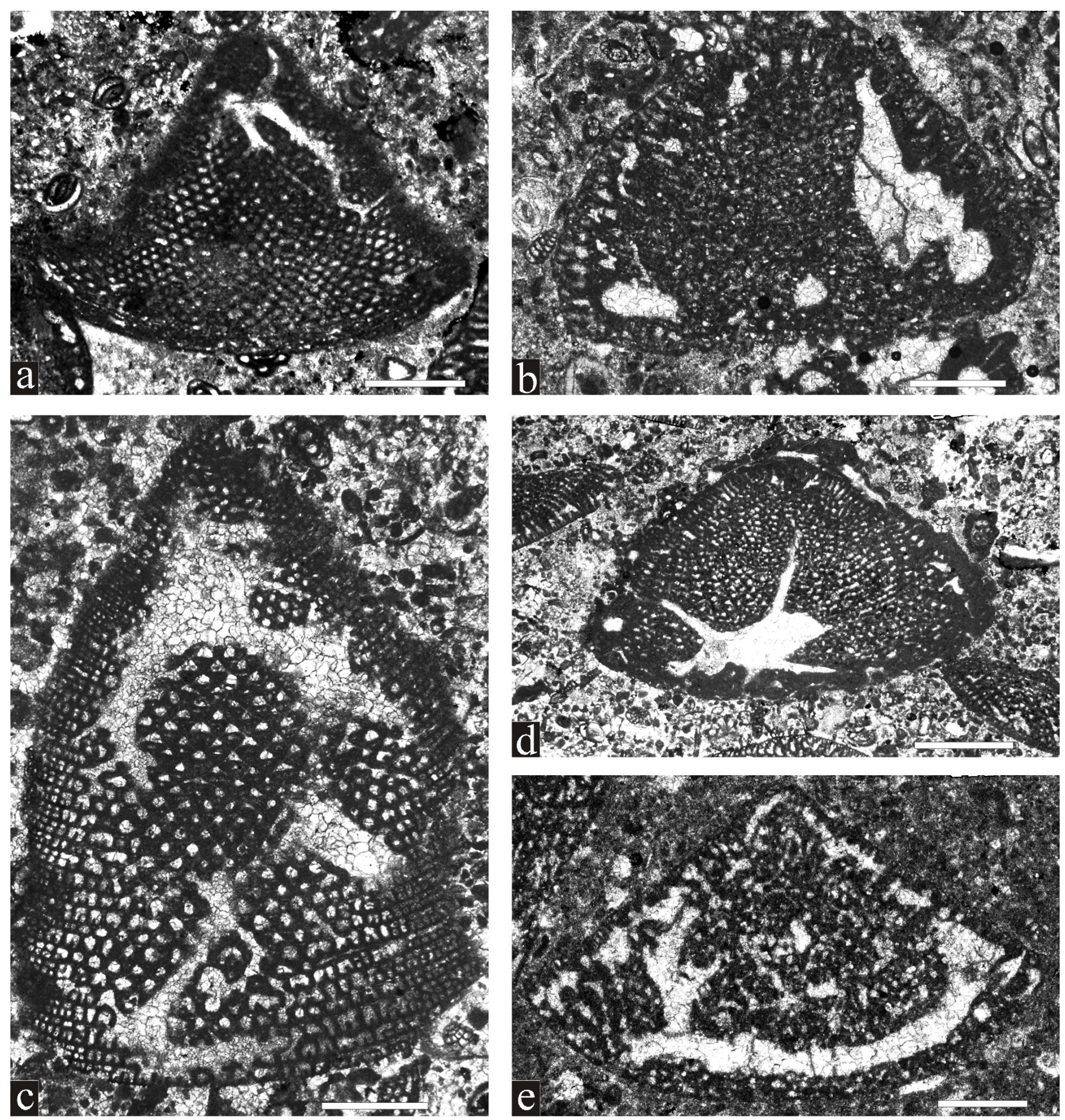

Fig. 4. Different sparite-filled traces (ichnogenus Entobia) ascribed to boring sponges from the Anarak section, Central Iran; a) Branching gallery of variable diameter. Note the thin micritic wall structure of unknown affinity.Thin-section AQ 24; $\boldsymbol{b}$ ) Bioeroded orbitolinid test showing a large cavity (chamber). Thin-section AQ 25; c) Boring gallery with swollen parts (chambers) and connecting canals. Thin-section AQ 49; d) Bioeroded test with one large chamber and radiating canals. Thin-section AQ 48; $\boldsymbol{e})$ Bioeroded test with a thick cylindrical canal running subparallel to the foraminiferan dorsal side. Thin-section $A Q 58$. Scale bars $1.0 \mathrm{~mm}=a, d, 0.5 \mathrm{~mm}=b, c, e$.

in question, however, they cannot be referred to the ichnogenus Entobia Bronn with certainty. However, endolithic sponges might cause these boring canals.

Borings associated with thaumatoporellaceans

In the Lower Cretaceous material from Iran, thaumatoporellaceans are common though not frequent. They occur within the micritic matrix or attached to the orbitolinid tests (Fig. 6b). Irregular ovoidal specimens are observed in shallow borings affecting the orbitolinid tests. The occupation of pre-existing cavities cannot be excluded so that a final conclusion about the status of these endoliths is not possible. Both thaumatoporellaceans within the matrix and borings exhibit rather thin walls (with poorly if ever visible pores) compared with, e.g., the Upper Cretaceous type-material (Pia, 1938; De Castro, 1990).

Endolithic tube of unknown affinity

A single section of a tube of unknown biogenic affinity was observed inside the central zone of an orbitolinid. The outer tube diameter is $5 \mu \mathrm{m}$ and the tube length may go up to $500 \mu \mathrm{m}$. The 

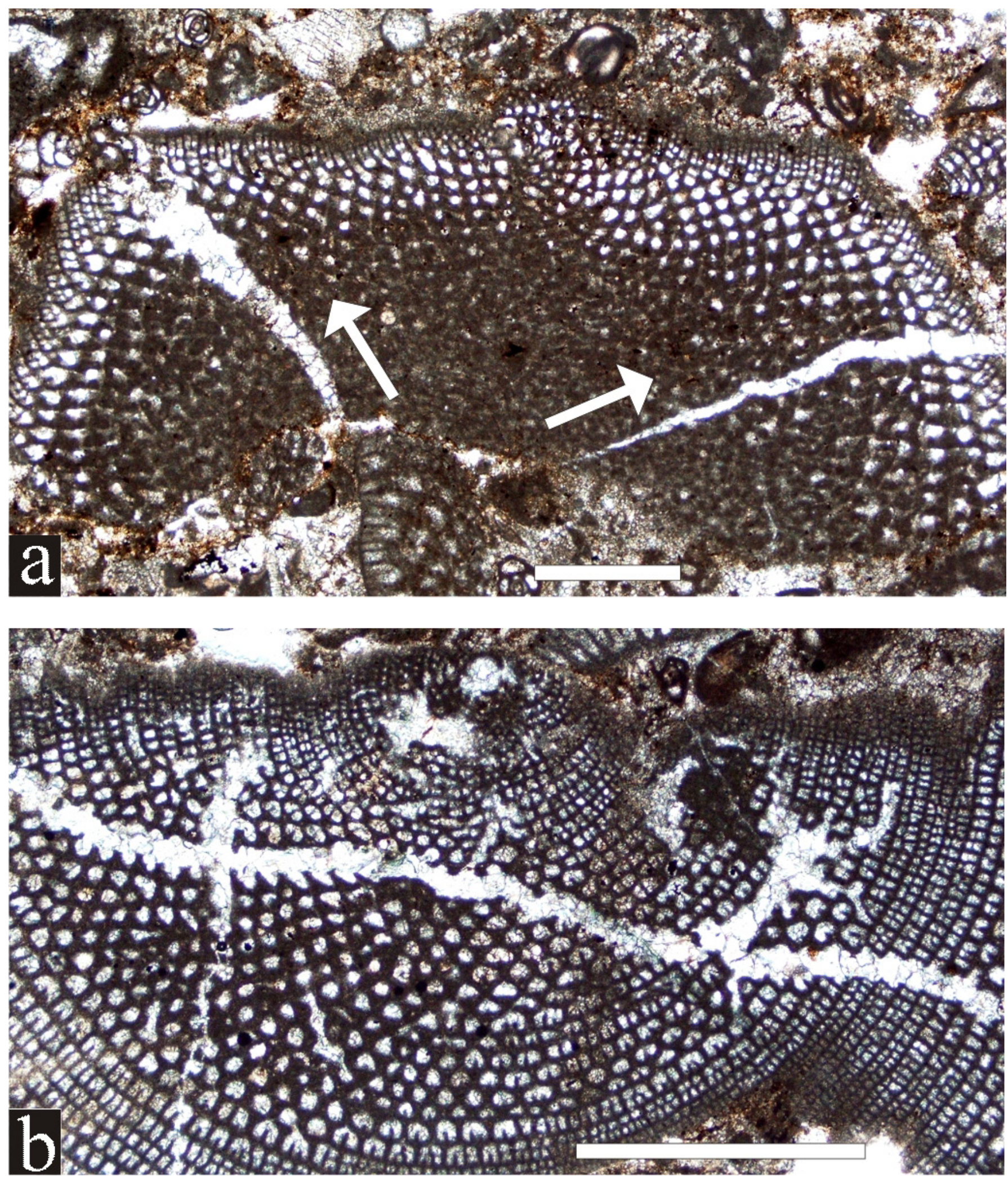

Fig. 5. Tubular, straight to slightly bending borings of unknown producer exhibiting increasing diameter and branching in $\boldsymbol{b}$. The assumed boring direction (starting from the test ventral side) in $\boldsymbol{a}$ is marked by the white arrows. Thin-section AQ 23. Scale bar $=0.5 \mathrm{~mm}$.

wall thickness is about $7 \mu \mathrm{m}$. The tube is similar to epibionts on orbitolinid tests (? sessile miliolids) (Fig. 7b).

\section{CONCLUSIONS}

Thin-section studies of Barremain-Aptian shallow-water carbonates from central Iran have yielded different bioerosional structures within orbitolinids. The observed traces can be related to the activity of calcimicrobial bacinellid crusts, the ichnogenus Entobia, endolithic tubes of unknown origin and possibly also thaumatoporellaceans. In several cases, the distinction between euendoliths and cryptoendoliths is not possible. The identified bioerosional structures were observed in foraminiferaldasycladalean wackestones to poorly washed packstones, a palaeoenvironment of supposedly relatively low rate of 

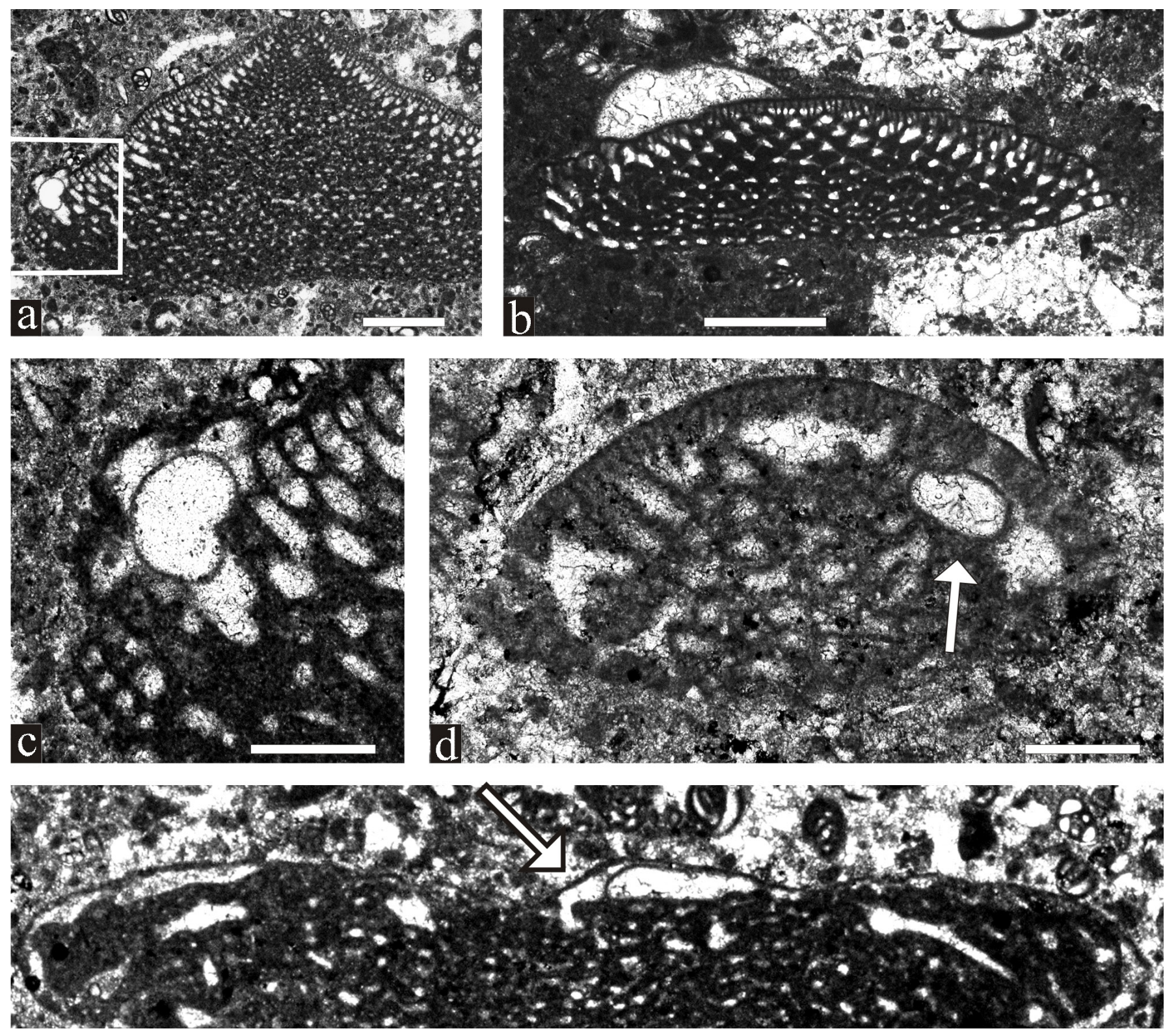

Fig. 6. Epi- and endolithic (euendolithic or cryptoendolithic) thaumatoporellaceans; a) Irregular spheroidal specimen inside a cavity affecting the orbitolinid marginal zone. Thin-section M 3; b) Epilithic specimens attaching to orbitolinid test. Thin-sections AQ 8; c) Detail from a; d) Euendolithic or cryptoendolithic specimen inside a bored cavity. Thin-section AQ 25; e) Flat conical orbitolinid test affected by various borings. Note the attaching thaumatoporellacean (arrow) at the ventral side stretching into a boring. Thin-section AQ 18 small; $\boldsymbol{f}$-g) Specimens inside borings. Thin-section AQn 24, AQ 18 small. Scale bars $=0.5 \mathrm{~mm}$, except $c-d=0.2 \mathrm{~mm}$.
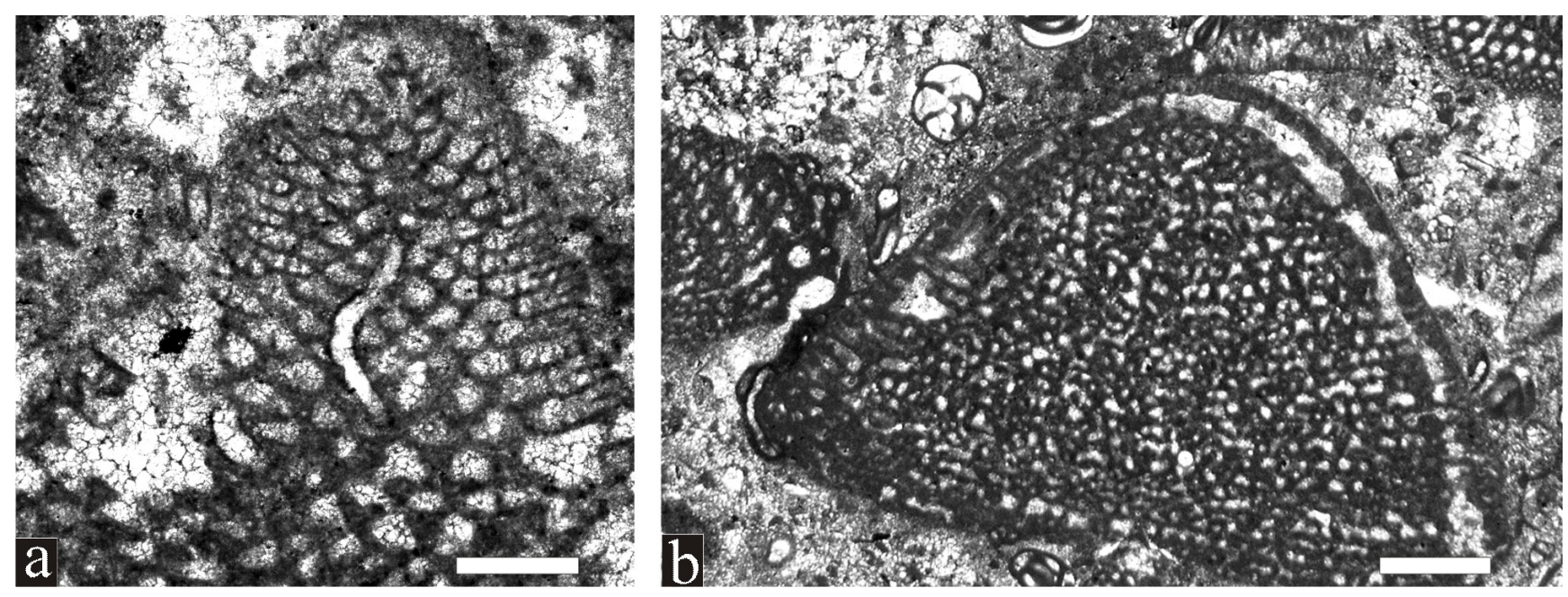

Fig. 7. a) Tubiform euendolith of unknown taxonomic position. Thin-section AQ 20; b) Epibiont (milioid foraminifer?) attached to an orbitolinid test (lower left margin) showing some similarities to the specimen in $\boldsymbol{a}$. Thin-section AQ 23. Scale bars $0.2 \mathrm{~mm}$ for a, $0.5 \mathrm{~mm}$ for $\boldsymbol{b}$. 
sedimentation allowing these organisms to act as bioeroders. The most common ichnotaxon is Entobia (Entobia ichnofacies). Preliminary results show that the intensity of bioerosion is much more intense in the Early Barremian than in the Lower Aptian samples. This observation might reflect the influence and possible change of longer-term environmental conditions (nutrients?). Such a link between evolutionary trends (e.g., abundances, speciation) and nutrition influx was discussed recently by Schroeder et al. (2010) for the orbitolinid fauna of the eastern Arabian plate (including southwest Iran).

Acknowledgements. Adrian Immenhauser (Bochum) and Stefan Huck (Hannover) are thanked for providing thin-sections used for comparisons in this study. Helpful remarks by the reviewers Markus Bertling (Münster) and Boguslav Kolodziej (Crakow) are kindly acknowledged.

\section{REFERENCES}

Aghanabati, A. 2004, The Geology of Iran. Geological Survey of Iran, 389 pp.

Banner, F.T. 1971, A new genus of the Planorbulinidae. An endoparasite of another foraminifer. Revista Española de Micropaleontología, 3: 113-128.

Berberian, M., King, G.C.P. 1981, Towards a palaeogeography and tectonic evolution of Iran. Canadian Journal of Earth Sciences, 18: 210-265. http://dx.doi.org/10.1139/e81-019

Berger, S., Kaever, M. J. 1992, Dasycladales. An illustrated monograph of a fascinating algal order. Georg Thieme Verlag, Stuttgart, 247 p.

Bertling, M., Braddy, S.J., Bromley, R.G., Demathieu, G.D., Genise, J., Mikuláš, R., Nielsen, J.K., Nielsen, K.S.S., Rindsberg, A.K., Schlirf, M. \& Uchman, A. 2006, Names for trace fossils: a uniform approach. Lethaia, 39 (3): 265-286. http://dx.doi.org/10.1080/002411606787890

Bromley, R.G. 2004, A stratigraphy of marine bioerosion. In McIlroy, D. (ed) The application of ichnology to palaeoenvironmental and stratigraphic analysis. Geological Society of London Special Publication, 228 (1): 455-479. http://dx.doi.org/10.1144/GSL.SP.2004.228.01.20

Bromley, R.G., D'Alessandro, A. 1984, The Ichnogenus Entobia from the Miocene, Pliocene and Pleistocene of Italy. Rivista Italiana di Paleontologia e Stratigrafia, 90 (2): 227-296.

Buchs, D., Bagheri, S., Martin, L., Hermann, J. \& Arculus, R. 2013. Paleozoic to Triassic ocean opening and closure preserved in Central Iran: Constraints from the geochemistry of meta-igneous rocks of the Anarak area. Lithos. http://dx.doi.org/10.1016/j.lithos.2013.02.009

Bucur, I.I., Rashidi, K. \& Senowbari-Daryan, B. 2012, Early Cretaceous calcareous algae from central Iran (Taft Formation, south of Alibad, near Yazd). Facies, 58 (4): 605-636. http://dx.doi.org/10.1007/s10347-012-0303-7

Chahida,M.R., Djafarian,M. 1977,ZweiRudistenvorkommen in der Kreide des zentralen Iran. Sitzungsberichte der Akademie der Wissenschaften, mathematischnaturwissenschaftliche Klasse, Abteilung I, 185: 295-306.

Cherchi, A., Kuss, J. \& Schroeder, R. 1990, Foraminiferi criptobionti in gusci di Orbitolina e in bio- e lithoclasti dell'Albiano di Gebel Maghara (Peninsola del Sinai, Egitto). In Atti del Quarto Simposio di Ecologia e Paleontologia delle Communità Bentoniche (Sorrento 1-5.11.1988) (Robba, E., Ed.). Torino (Museo Regionale di Scienze Naturali), p. 151-178.
Ćosović, V. Drobne, K. \& Ibrahimpašić, H. 2012, The role of taphonomic features in the palaeoecological interpretation of Eocene carbonates from the Adriatic carbonate platform (PgAdCP). Neues Jahrbuch für Geologie und Paläontologie, Abhandlungen, 265 (2), 101-112. http://dx.doi.org/10.1127/0077-7749/2012/0249

De Castro, P. 1990, Thaumatoporelle: Conoscenze attuali e approcio all'interpretazione. Bolletino della Societá Paleontologica Italiana, 29: 179-206.

De Gibert, J.M., Martinell, J. \& Domenech, R. 1998, Entobia ichnofacies in fossil rocky shores, lower Pliocene, northwestern Mediterranean. Palaios 13 (5): 476-487. http://dx.doi.org/10.2307/3515475

Ercegovic, A. 1927, Three new genera of lithophytic Cyanophceae from the Adriatic coast). Acta Botanica Instituti Botanici Universitatis Zagrebensis, 2: 78-84 (in Serbian).

Flügel, E. 2004, Microfacies of Carbonate Rocks - analysis, interpretation and application. Springer, Berlin, $976 \mathrm{p}$.

Glaub, I. 1994, Mikrobohrspuren in ausgewählten Ablagerungsräumen des europäischen Jura und der Unterkreide (Klassifikation und Palökologie). Courier Forschungsinstitut Senckenberg, 174: 1-324.

Golubic, S., Campbell, S.E., Drobne, K., Cameron, B., Balsam, W.L., Cimerman, F. \& Dubois, L. 1984, Microbial endoliths: a benthic overprint in the sedimentary record, and a paleobathymetric cross-reference with foraminifera. Journal of Paleontology, 58 (2): 351-361.

Golubic, S., Friedmann, I. \& Schneider, J. 1981, The lithobiontic ecological niche, with special reference to microorganisms. Journal of Sedimentary Petrology, 51 (2): 475-478.

Golubic, S., Perkins, R.S. \& Lucas, K.J. 1975, Boring microorganisms and microborings in carbonate substrates. In The study of Trace Fossils (Frey, R.W., Ed.). Springer, Berlin, p. 229-259. http://dx.doi.org/10.1007/978-3-642-65923-2 12

Granier, B. 2003, Cretaceous calcareous algae and microbial carbonates from Prebetic Zone (Betic Cordillera, E Spain). In $8^{\text {th }}$ International Symposium Fossil Algae. Field Trip Guide Book. Publ. Univ. Granada (Braga, J.C. \& Guirre, J., Eds.), p. 25-34.

Kolodziej, B. 1997, Boring foraminifera from exotics of the Štramberk-type limestones (Tithonian-Lower Berriasian, Polish Carpathians). Annales Societatis Geologorum Poloniae, 67: 249-256.

Mägdefrau, K. 1932, Über einige Bohrgänge aus dem unteren Muschelkalk von Jena. Paläontologische Zeitschrift, 14 (3): 150-160. http://dx.doi.org/10.1007/BF03041628

Matteucci, R. 1978, Foraminiferi epibionti e criptobionti in gusci di Nummuliti dell'Eocene medio del Gargano (Puglia). Geologica Romana, 17: 389-410.

Maurin, A.F., Bernet-Rollande, M.C., Monty, C.L.V. \& Nazhat, S. 1985, The microbial nature of bacinellid textures. Sedimentological bearings. $9^{\text {th }}$ European regional meeting of sedimentology, Leiden, abstracts, p. 285-287.

Nebelsick, J.N., Bassi, D. \& Rasser, M.W.2011, Microtaphofacies: Exploring the Potential for Taphonomic Analysis in Carbonates. In Taphonomy Process and bias through time, $2^{\text {nd }}$ ed. (Allison, P.A. \& Bottjer, D.J., Eds.). Springer, Dordrecht, Heidelberg, London, New York, p. 337-374.

Neumann, A.C. 1966, Observations on coastal erosion in Bermuda and measurement of the boring rate of the sponge Cliona lampa. Limnology and Oceanography, 11: 92-108. http://dx.doi.org/10.4319/10.1966.11.1.0092 
Neuweiler, F., Reitner, J. 1992, Karbonatbänke mit Lithocodium aggregatum Elliott / Bacinella irregularis Radoičić. Paläobathymetrie, Paläoökologie und stratigraphisches Äquivalent zu thrombolithischen Mud Mounds. Berliner geowissenschaftliche Abhandlungen, (E) 3: 273-293.

Nielsen, J.K. 2002, Borings formed by Late Cretaceous endobiontic foraminifers within larger benthic foraminifers. Acta Palaeontologica Poloniae, 47 (4): 673-678.

Nielsen, J.K., Görmüş, M. 2004, Ichnotaxonomy and ethology of borings in shallow-marine benthic foraminifers from the Maastrichtian and Eocene of northwestern and southwestern Turkey. Rivista Italiana di Paleontologia e Stratigrafia, 110 (2): 493-501.

Pia, J. 1938, Über Thaumatoporella parvovesiculifera Rain. spec. und ihr Auftreten auf der Insel Naxos. Praktika tès Akadèmias Athènon, 13: 491-495.

Schäfer, P., Senowbari-Daryan, B. 1983, Die Kalkalgen aus der Obertrias von Hydra, Griechenland. Palaeontographica $B, 185: 83-14$.

Schlagintweit, F., Bover-Arnal, T. 2012, Remarks on Bacinella Radoičić, 1959 (type-species B. irregularis) and its representatives. Facies, 59 (1): 59-73. http://dx.doi.org/10.1007/s10347-012-0309-1

Schlagintweit, F., Bucur, I.I., Rashidi, K. \& Saberzadeh, B. 2013, Praeorbitolina claveli n. sp. (benthic foraminifera) from the Lower Aptian sensu stricto (Bedoulian) of Central Iran. Carnets de Géologie / Notebooks on Geology, Letter 2013/04, 255-272.

Schroeder, R. 1997, Remarques sur une prétendue association de Palorbitolina lenticularis/Valserina broennimanni dans le Jura neuchâtelois. Ecologae Geologica Helvetiae, 90: 263-267.

Schroeder, R., van Buchem, F.S.P., Cherchi, A., Baghbani, D., Vincent, B., Immenhauser, A. \& Granier, B. 2010, Revised orbitolinid biostratigraphic zonation for the BarremianAptian of the eastern Arabian Plate and implications for regional stratigraphic correlations. GeoArabia Special Publication, 4: 49-96.

Scoffin, T.P., Bradshaw, C. 2000, The taphonomic significance of endoliths in dead -versus live- coral skeletons. Palaios, 15 (3): 248-254.

http://dx.doi.org/10.1669/0883-1351(2000)015<0248:TTS $\mathrm{OEI}>2.0 . \mathrm{CO} ; 2$
Sen-Gupta, S., Nielsen, J.K. 2009, Bioerosion in Middle Eocene larger foraminifera Nummulites obtusus (SOWERBY) from Lakhpat, northwest Kutch, Gajarat, India. Indian Journal of Geosciences, 63 (1), 81-86.

Stöcklin, J. 1971, Stratigraphic lexicon of Iran Part 1: Central, North and East Iran. Geological Survey of Iran, Report 18, 1-338.

Taylor, P.D., Wilson, M.A. 2003, Palaeoecology and evolution of marine hard substrates. Earth Science Reviews, 62 (1): 1-103. http://dx.doi.org/10.1016/S0012-8252(02)00131-9

Titschack, J., Bromley, R.G. \& Freiwald, A. 2005, PlioPleistocene cliff-bound, wedge-shaped, warm-temperate carbonate deposits from Rhodes (Greece): Sedimentology and facies. Sedimentary Geology, 180 (1-2): 29-56.

http://dx.doi.org/10.1016/j.sedgeo.2005.06.009

Torabi, G. 2011, Late Permian blueschist from Anarak ophiolite (Central Iran, Isfahan province), a mark of multisuture closure of the Paleo-Tethys ocean. Revista Mexicana de Ciencas Geológicas, 28 (3): 544-555.

Tribollet, A. 2008, The boring microflora in modern coral reef ecosystems: a review of its roles. In Current developments in bioerosion (Wisshak, M. \& Tapanila, L., Eds.). Springer, Berlin, Heidelberg, p. 67-94. http://dx.doi.org/10.1007/978-3-540-77598-0 4

Uţă, A., Bucur, I.I. 2003, Microbial structures and microencrusters in the Upper Jurassic-Lower Cretaceous deposits from Buila-Vânturariţa Massif (South Carpathians). Studia UBB Geologia, 48: 3-14.

Vachard, D., Hauser, M., Martini, R., Zaninetti, L., Matter, A. \& Peters, T. 2001, New algae and problematica of algal affinity from the Permian of the Aseelah Unit of the Batain Plain (East Oman). Géobios, 34: 375-404. http://dx.doi.org/10.1016/S0016-6995(01)80003-6

Wilmsen, M., Fürsich, T., F. \& Majidifard, M. R. 2013, The Shah Kuh Formation, a latest Barremian-Early Aptian carbonate platform of Central Iran (Khur area, Yazd Block). Cretaceous Research, 39: 183-194. http://dx.doi.org/10.1016/j.cretres.2012.02.013

Wilson, M.A. 2007, Macroborings and the evolution of marine bioerosion. In Trace fossils - concepts, problems, prospects (Miller, W. III., Ed.). Elsevier, Amsterdam, p. 356-367. http://dx.doi.org/10.1016/B978-044452949-7/50146-7 